FIU Law Review

Fall 2009

\title{
Judicial Cincinnati: The Humble Heroism of Originalist Justices
}

Daniel R. Suhr

Follow this and additional works at: https://ecollections.law.fiu.edu/lawreview

Part of the Other Law Commons

Online ISSN: 2643-7759

Recommended Citation

Daniel R. Suhr, Judicial Cincinnati: The Humble Heroism of Originalist Justices, 5 FIU L. Rev. 155 (2009).

DOI: https://dx.doi.org/10.25148/lawrev.5.1.11

This Article is brought to you for free and open access by eCollections. It has been accepted for inclusion in FIU Law Review by an authorized editor of eCollections. For more information, please contact lisdavis@fiu.edu. 


\title{
Judicial Cincinnati: The Humble Heroism of Originalist Justices
}

\author{
Daniel R. Suhr
}

“'Let us now praise famous men' was not a gesture of pietistic generosity, the placing of verbal flowers on the graves of famous men. It is for our sake that we praise them, for, as Ecclesiasticus added, they have given us an 'inheritance.' We commune with them to enlighten our understanding of the significance of life, to refine our faculties as assayers of values, to fortify our will in pursuing worthy ends."

- Justice Felix Frankfurter, 1957

\section{INTRODUCTION}

When we speak of heroes, we usually refer to men and women of great achievement: conquerors, innovators, explorers, trailblazers, warriors. Courage, cunning, and creativity are their attributes, and triumph over adversity is their aim. Sometimes these heroes undertake their endeavors from the heights of power - generals, kings and queens, captains of industry and science. Other times they undertake them from the bottom of society champions of the little guy, challengers of the unjust status quo. Our heroes of history are reinforced by our heroes from Hollywood and HarperCollins - the doing of great deeds makes for more interesting stories.

This typology of heroism seeps into the legal community as much as any other area of our common culture. Thus, the "trial lawyer of the century" is Clarence Darrow, who always argued the case for the underdog. The appellate attorney of the century is Thurgood Marshall, advocate for and architect of a more just society. On the bench, justices who transformed jurisprudence, and through it society, such as Earl Warren and William Brennan, are designated as heroes.

* Honors B.A., cum laude, and J.D., cum laude, Marquette University. Licensed to practice in Wisconsin, Suhr works in Washington, D.C. Thank you to Matthew J. Glover, Brock Dahl, Andrew Hitt, and Matthew Fernholz for the helpful comments and encouragement.

1 Felix Frankfurter, The Supreme Court in the Mirror of Justices, 105 U. PA. L. REV. 781, 781 (1957) (quoting Ecclesiasticus 44:1-22). 
But another type of hero, though much less publicly discussed, is perhaps more intriguing, even more praiseworthy. Though it may be heroic to achieve and use great power, it is at least as noble to achieve great power, and then to set it aside in service to society. The foremost historical example of such heroic self-denial is the legendary Roman general Cincinnatus. When another tribe threatened Rome, the Roman Senate voted to invest Cincinnatus with the emergency authority of "dictator," which gave him total control of the state. Cincinnatus took up the task, won the war, and then returned peaceably to his farm, refusing the opportunity to seize power as the permanent ruler of Rome. There are few examples of such heroes in history or literature - one may think only of the American Cincinnatus, George Washington, and perhaps of Frodo Baggins, bearer of the ring of power in Tolkien's Lord of the Rings.

Though they do not usually make the lists of "The Greatest Justices," jurists who devote themselves to the rule of law and the methodology of originalism practice this rarer form of heroism. As we will see in the examples from the Warren Court, Supreme Court justices have the opportunity to wield their pens and powers to shape American society according to their own vision of what is just. Some justices insist on denying themselves this opportunity; seeing it instead as a temptation, they believe that the proper role of the judge is modest and humble - to carry out the will of the political branches by applying the enacted law to the facts before them. This humble approach to the judicial role follows in the heroic tradition of Cincinnatus, self-control in service to the republic and the rule of law.

This essay begins by making a few foundational observations about the importance of heroes to our legal system. It is not simply that we enjoy the exercise of ranking great justices, though we do, but that the elevation of heroes serves an important pedagogical function, teaching all lawyers and the community at large about what virtues to value. Thus, the legal profession, especially the legal academics who usually sponsor these exercises, should take seriously the implications of their activities. Second, this essay outlines the usual conception of active, crusading, conquering heroes. It then shows how and why the legal community has canonized two leaders of the Warren Court - Chief Justice Earl Warren and Justice William Brennan - as "heroic justices." Finally, this essay looks at the "humble heroism" exhibited by Cincinnatus and Frodo Baggins. It then connects this humble heroism to the judicial context by identifying it with an originalist method of interpretation driven by service to the rule of law.

\section{The Pedagogical FunCtion OF HeRoes}

In his diary entry for March 14, 1891, Supreme Court Justice Joseph P. Bradley identified a favored pastime for generations of lawyers. "As long 
as the Republic goes on," he wrote, "men will reread the Reports and ask, as we have been asking here: Who were the great Justices?"2 Some seek answers to this question by way of citation studies; ${ }^{3}$ others give only their own personal judgments; ${ }^{4}$ yet others survey and aggregate the personal judgments of numerous professors and practitioners. ${ }^{5}$ All of these efforts are undertaken for more than mere fancy or passing interest - we learn much from the examples of great justices in the past. ${ }^{6}$

The stories of great justices shape professional ideals, setting the standards of excellence for current judges. Presidents will look to heroic justices of the past for inspiration and models for their own judicial nominations, so that their nominees may share these virtues. ${ }^{7}$ Once on the bench, judges will seek to emulate the lead of judicial heroes. ${ }^{8}$ If justices, like presidents,

2 Charles Fairman, What Makes a Great Justice? Mr. Justice Bradley and the Supreme Court, 1870-1892, 30 B.U. L. REV. 49, 102 (1950).

3 See, e.g., Mitu Gulati \& Veronica Sanchez, Giants in a World of Pygmies? Testing the Superstar Hypothesis with Judicial Opinions in Casebooks, 87 IowA L. REV. 1141 (2002); Russell Smyth \& Mita Bhattacharya, What Determines Judicial Prestige? An Empirical Analysis for Judges of the Federal Court of Australia, 5 AM. L. \& ECON. REV. 233 (2003); Michael E. Solimine, Judicial Stratification and the Reputations of the United States Courts of Appeals, 32 FLA. ST. U. L. REV. 1331 (2005). But see Jay S. Bybee \& Thomas J. Miles, Judging the Tournament, 32 FLA. ST. U. L. REV. 1055 (2005); Steven Goldberg, Federal Judges and the Heisman Trophy, 32 FLA. ST. U. L. REV. 1237 (2005).

4 See, e.g., Charles Evans Hughes, The Supreme Court of the United States 58 (Columbia Univ. Press 1928); Roscoe Pound, The Formative Era of American LaW 30-31 n.2 (Little Brown and Co. 1938); Frankfurter, supra note 1, at 783-84; John P. FranK, MARBle Palace: The Supreme Court In AMERICAN Life (Alfred A. Knopf 1958); George R. Currie, A Judicial All-Star Nine, 1964 Wis. L. REV. 3; Sidney H. Asch, The Supreme Court AND Its Greatest Justices (Arco Publishing Co., Inc. 1971); Bernard Schwartz, The Judicial Ten: America's Greatest Justices, 4 S. ILL. U. L.J. 405 (1979) [hereinafter Schwartz, Judicial Ten]; Bernard Schwartz, Supreme Court Superstars: The Ten Greatest Justices, 31 TulSA L.J. 93 (1995) [hereinafter Schwartz, Superstars].

5 See, e.g., William D. Pederson and norman W. Provizer, Great Justices of the U.S. Supreme CourT: RATINGS ANd CASES (Peter Lang Publishing 1993); Roy Mersky \& Albert Blaustein, Rating Supreme Court Justices, 58 A.B.A. J. 1185 (1972). For a critique of the literature ranking justices, see G. Edward White, Neglected Justices: Discounting for History, 62 VAND. L. REV. 319 (2009).

6 See Schwartz, Judicial Ten, supra note 4, at 443 ("Great men are the guide-posts and landmarks in the law, as they are in the state.").

7 See William G. Ross, The Ratings Game: Factors that Influence Judicial Reputation, 79 MARQ. L. REV. 401, 402 (1996) ("[T] he evaluation of justices helps us to discriminate among possible candidates for service on the Court ....”). For instance, when President Clinton introduced Ruth Bader Ginsburg as his nominee in 1993, he compared her to the great justice whom she was replacing, saying, "Many admirers of her work say that she is to the women's movement what former Supreme Court Justice Thurgood Marshall was to the movement for the rights of African-Americans." William J. Clinton, "Remarks Announcing the Nomination of Ruth Bader Ginsburg to Be a Supreme Court Associate Justice," June 14, 1993, The American Presidency Project, http://www.presidency.ucsb.edu/ws?pid=466 84.

8 See Paul W. Kahn, Owen Fiss: Heroism in the Law, 58 U. Miami L. ReV. 103, 103 (2003) (Professor Owen Fiss, for instance, dedicated a great portion of his scholarly career to "defend[ing] judicial heroes: Justices like Brennan and Marshall. He erected a scholarly apparatus that justified their actions and encouraged other judges to follow their lead." (emphasis added)). 
obsess over their expected historical legacies, then they will adapt their behavior to better mirror the decisions of past justices who possess such desirable verdicts from history. ${ }^{9}$

Not only jurists, but practicing attorneys as well are affected by these role models. "The stories of the profession helped define who lawyers are and their role in society." "They are "great examples, not just for posterity, but for . . . lawyers practicing today so that all of us can learn from lives well lived ...."11 They serve as role models; " "[t]heir accomplishments serve as bright beacons by which we all try to chart our own actions and values." "For example, the advocates responsible for iconic public interest cases are usually considered "heroic," which encourages young lawyers to bring new "impact" litigation cases that "push" the law in a particular direction.

This role modeling function is especially important for law school students, whose values and expectations for their budding legal careers are still largely undefined. Thus, Professor Andrew Watson recommends, "[1]aw schools must provide students with 'heroes for emulation.' . . The ultimate purpose . . . is to supply students with a variety of desirable models after which they can pattern their professional career." form a particular function encouraging students to pursue a career path where they "resist a powerful dominant culture in order to pursue their goals." 16

The community at large also learns from the particular justices whom we designate as great, because they reflect the legal profession's judgment of the "proper relationship between the profession and the greater community." 17 By elevating justices as heroes, the legal community tells the citi-

9 See Jason J. Czarnezki, Voting and Electoral Politics in the Wisconsin Supreme Court, 87 MARQ. L. REV. 323 (2003) (arguing that Wisconsin Supreme Court justices adjust their behavior in criminal cases based on how close they are to an election).

10 Gretchen A. Jackson, The Lawyer's Myth: Reviving Ideals in the Legal Profession, 179 MIL. L. REV. 228, 231 (2004).

11 Harper Estes, My Heroes Have Always Been Lawyers, 72 TEXAs B.J. 556, 667 (2009) (announcing the launch of the "Texas Legal Legends" initiative, which will archive oral history interviews with great Texas lawyers).

12 See Donald H.J. Hermann, Patterns of a Life in the Law: A Consideration of Contemporary American Legal Biography, 24 DePAul L. REV. 853, 854 (1975).

13 James D. Cox, Heroes in the Law: Alford v. Shaw, 66 N.C. L. REv. 565, 565 (1988).

14 See Judge Dennis Jacobs, Remarks before the Rochester Lawyers Chapter of the Federalist Society (Oct. 6, 2008) (transcript available at http://www.fed-soc.org/publications/pubid.1178/pub_detai 1.asp) (discussing the "glamour" that is conferred by "impact" public interest litigation).

15 Andrew S. Watson, The Quest for Professional Competence: Psychological Aspects of Legal Education, 37 U. CIN. L. REV. 93, 158 (1968).

16 Kirsten Edwards, Found! The Lost Lawyer, 70 FordHAm L. ReV. 37, 59 (2001).

17 Jackson, supra note 10, at 231. 
zenry at large that this is what we believe judges ought to do. Citizens internalize this information and may set it as their own expectation for judicial behavior. ${ }^{18}$

In sum, then, who we decide are the heroes matters. Current justices, especially those who are concerned about their future legacy, will pattern their behavior and decision-making after justices whose legacies are oftpraised. Lawyers will bring cases that offer judges opportunities to shape and transform the law. Law students will plan careers that offer an opportunity to seek sustained change in the law. And citizens in the community will expect judges to act "heroically" when considering cases, whether their own or simply cases in general. Whether the legal community lionizes or lambasts a justice as a hero or villain shapes cultural attitudes about judges - and the law generally.

\section{THE LIBERALS WE LIONIZE}

Joseph Campbell, whose book, The Hero with a Thousand Faces, is the definitive analysis of the hero character in mythology, and describes the archetypal hero as "the carrier of the shining blade, whose blow . . . will liberate the land." 19 Usually such a hero must call upon a great internal reservoir of personal courage to strike such a blow. ${ }^{20}$

This courageous, crusading conception of the hero carries over into the law; often we speak of heroic lawyers as those who bring important cases that seek justice for oppressed or downtrodden clients. ${ }^{21}$ Harvard Law's Charles Olgetree draws on this tradition when he defines heroism in the law as 'the desire to take on 'the system' and prevail, even in the face of overwhelming odds." 22 Thus, we look upon Clarence Darrow as a hero for his defense of unpopular criminal defendants. ${ }^{23}$ The Texas State Bar labeled

18 This is especially possible when the profession that lay people are evaluating is a complex, technical craft shrouded in mystery and historically considered as trustable and respectable.

19 Joseph Campbell, The Hero with a Thousand Faces 16 (Princeton Univ. Press, 2d ed. 1968). It is worth noting that one could choose to emphasize character more and action and impact less when defining heroism. See, e.g., Clarence Thomas, Victims and Heroes in the 'Benevolent State,' 19 HARV. J.L. \& PUB. POL'Y 671 (1996).

20 See, e.g., Margaret Mark \& Carol S. Pearson, The Hero and the Outlaw 106 (McGraw-Hill 2001).

21 See, e.g., Gregory C. Keating, The Heroic Enterprise of the Asbestos Cases, 7 Sw. U. L. REV. 623 (2008); Wayne J. Lee, Lawyers Can Be Heroes, 51 LA. B.J. 326, 327 (2004) (describing lawyers from the Civil Rights era as "courageous" and "heroic").

22 Charles J. Ogletree, Jr., Beyond Justifications: Seeking Motivations to Sustain Public Defenders, 106 HARV. L. REV. 1239, 1243 (1993).

23 Scott W. Howe, Reassessing the Individualization Mandate in Capital Sentencing: Darrow's Defense of Leopold and Loeb, 79 IowA L. REv. 989, 998 n.51 (1994) (quoting U. MicH. L. SCH. BuLL., 
Sarah Weddington a "legal legend" for serving as the lead counsel in Roe $v$. Wade and as a pioneer in the cause of women's rights. ${ }^{24}$ The New York Times' report on the death of Thurgood Marshall hailed him as a "civil rights hero" in the banner headline.

Justices of the Supreme Court and other judges can also achieve hero status. $^{26}$ As it is, lawyers and legal academics already look upon judges as possessing a special status as the foremost members of the profession "princes" in law's empire. ${ }^{27}$ Indeed, we sometimes use heroic terms to describe judges: "demigod," 28 "lions," "29 "judicial titans," 30 a "lawyer of superhuman skill" known as Judge "Hercules," and occupants of the "pantheon of the great American judges.",

Unsurprisingly, the legal community's criteria for ascribing "hero" status to justices track closely the more general attributes that culture expects from its heroes. ${ }^{33}$ Heroic judges are courageous ${ }^{34}$ - they "use power expan-

Mar. 24, 1976, at 8); Gerald F. Uelmen, Who is the Lawyer of the Century?, 33 LOY. L.A. L. REV. 613 (2000).

24 See Texas Legal Legends, State Bar of Texas, http://www.texasbar.com/Template.cfm?Sectio $\mathrm{N}=$ Home\&CONTENTID=24650\&TEMPLATE $=/$ ContentManagement/ContentDisplay.cfm (last visited Mar. 19, 2010).

25 Linda Greenhouse, Thurgood Marshall, Civil Rights Hero, Dies at 84, N.Y. Times, Jan. 25, 1993, available at http://www.nytimes.com/1993/01/25/us/thurgood-marshall-civil-rights-hero-dies-at84.html.

26 I note here that one does not achieve hero status as much as one is accorded hero status by "a mixed host of scheming angels made up of any combination of political scientists, law professors, journalists, dramatists, and professional opinion molders." John Phillip Reid, Beneath the Titans, 70 N.Y.U. L. REV. 653, 662 (1995); see also James W. Ely, Jr. \& Mark E. Brandon, Symposium on Neglected Justices, 62 VAND. L. REV. 311, 314 (2009) ("The rankings of Holmes and Louis D. Brandeis, in particular, have benefited from active promotion of their 'greatness' by devoted cheerleaders.")

27 RONALD DWORKIN, LAW’s EMPIRE 407 (Belknap Press 1986).

28 John P. Frank, Book Review, The Great Judge, 108 HARV. L. REV. 931, 931 (1995).

29 Gregory C. Sisk, Uprooting the Pruneyard, 38 RUTGERS L.J. 1145, 1156 (2007).

30 Sarah Barringer Gordon, The Creation of a Usable Judicial Past, 70 N.Y.U. L. REv. 622, 623 (1995).

31 Ronald Dworkin, TAKIng Rights Seriously 105-06 (Harvard Univ. Press 1978).

32 David Breen, Avoiding 'Wild Blue Yonders': The Prudentialism of Henry J. Friendly and John Roberts, 52 S.D. L. REV. 73, 73 (2007).

33 In the law we usually look only at the professional achievements of a "great justice," setting aside most considerations of his or her personal life. See Paul Gewirtz, A Lawyer's Death, 100 HARV. L. REV. 2053, 2055-56 (1987); see also Richard Posner, Judicial Biography, 70 N.Y.U. L. REV. 502, 512 (1995).

34 See Cynthia L. Fountaine, In the Shadow of Atticus Finch: Constructing a Heroic Lawyer, 13 WIDENER L.J. 123, 139-40 (2003) ("To be heroic, lawyers must be courageous. They must have the courage to follow their consciences. This, of course, includes the courage to stand up to one's adversaries, to judges, and to others to loyally represent the clients' interests and advocate on behalf of the client. Perhaps even more challenging, however, is that lawyers must have the courage to stand up to friends, colleagues, employers, partners, and even the general public and act according to their own consciences in representing their clients."); H.M. MacMillan, My Heroes Have Always Been Lawyers, WYO. LAWYER, Oct. 24, 2001 at 13, 14 ("[P]erhaps the greatest quality that we lawyers share and bring 
sively, even heroically" to right social wrongs. ${ }^{35}$ In doing so, they demonstrate "the willingness to risk the misunderstandings that so often come when people do the heroic thing." 36 They are men of action, "us[ing] the power of the bench to the full." 37 They challenge the status quo, ${ }^{38}$ exercising that "prophetic vision," which enables them to "strive to decide constitutional issues in a way that will stand the test of time rather than conform to accepted standards of the present." ${ }^{, 39}$ They seek widespread changes in the law - "Indeed, who could fail to be swept away by stories of great legal reformers?" 40 They may even be "pioneers" ${ }^{41}$ or inventors of a new philosophy for jurisprudence or even for society at large. ${ }^{42}$ Professor Cynthia

to bear is our courage."); see also Constance Frisby Fain, Characteristics of the Heroic Lawyer and Avoidance of Unprofessional Conduct, 13 WIDENER L.J. 61, 62 (2003).

35 David Luban, Heroic Judging in an Antiheroic Age, 97 Colum. L. Rev. 2064, 2065 (1997). Judge Patricia Wald rephrased this statement as a question, asking "when is it appropriate for unelected, life-tenured judges to exercise fearlessly the kind of raw power that is usually thought to be the essence of heroism.” Patricia Wald, Remembering a Constitutional Hero, 43 N.Y.L. SCH. L. REV. 13, 27 (1999).

36 John T. Noonan, Jr., Education, Intelligence, and Character in Judges, 71 MINN. L. REV. 1119, 1131 (1987) (quoting Justice Louis Brandeis: "The government, he said, wants employees who 'add to the virtue of obedience some other virtues - the virtues of manliness, of truth, of courage, of willingness to risk positions, of the willingness to risk criticisms, of the willingness to risk the misunderstandings that so often come when people do the heroic thing."').

37 Schwartz, Judicial Ten, supra note 4, at 445 (" $[\mathrm{H}]$ istory has a natural bias in favor of the strong leader. This is true of judges as it is of presidents . . In legal, as in political, history, exercise of power glamorizes. . . All of those on our list used the power of the bench to the full."). See Norman Dorsen and Christopher L. Eisgruber, Preface: Symposium: National Conference on Judicial Biography, 70 N.Y.U. L. REV. 485, 485 (1995)

38 W. Bradley Wendel, Our Love-Hate Relationship with Heroic Lawyers, 13 WIDENER L.J. 1, 3 (2003) ("One consistent theme in lawyer-hero stories is the battle with 'fabulous forces' - often powerful people or institutions that stand in the way of the lawyer's success. The struggle may be described as physical or moral, but there is always the element of opposition by powerful forces, and, ultimately, victory over those forces by the hero."); see Orit Kamir, Michael Clayton, Hollywood's Contemporary Hero-Lawyer: Beyond Outsider Within and Insider Without, 42 Suffolk U. L. REV. 829, 829 (2009) (defining the lawyer-hero from 1960s' cinema as "paving the way to progressive social change."); Michael J. Klarman, Brown, Originalism, and Constitutional Theory: A Reply to Professor McConnell, 81 VA. L. REV. 1881, 1933-34 (1995) (first using the term "countermajoritarian hero" in reference to the work of the Court).

39 Currie, supra note 4, at 3.

40 See Gail Heriot, Songs of Experience: The Lost Lawyer, 81 VA. L. REV. 1721, 1750 n.91 (1995).

41 Ross, supra note 7, at 405.

42 G. Edward White, The Canonization of Holmes and Brandeis: Epistemology and Judicial Reputations, 70 N.Y.U. L. REV. 576 (1995) (explaining how Holmes and Brandeis have achieved heroic, iconic status in the law and society more broadly because they were leading exponents of a broader philosophy concerning history and human agency); see Ruth Anne Robbins, Harry Potter, Ruby Slippers and Merlin: Telling the Client's Story Using the Characters and Paradigm of the Archetypal Hero's Journey, 29 SEATTLE U. L. REV. 767, 770 (2005) ("We are not afraid to characterize a lawyer or judge as 'pioneering' a field or policy in law."); Richard Posner, The Learned Hand Biography and the Question of Judicial Greatness, 104 YALE L.J. 511, 523 (1994) (reviewing GERALD GunTHER, LEARNED HAND: 
Fountaine says that heroic lawyers must be "compassionate," which she equates with "empathy." 43 They press for the expansion of civil liberties and individual rights. ${ }^{44}$ Like Robin Hood, they fight for the rights and liberties of the poor, oppressed, and downtrodden. ${ }^{45}$ Like Batman, the Lone Ranger, and Zorro, "[t]heir primary interest is in justice, not in the letter of the law." "46 Reviewing all these attributes, we might paraphrase a famous cliché to say, accurately, “One man's judicial activist is another's judicial hero."

In the second half of the twentieth century, two justices achieved this heroic status. Rankings of "great" justices consistently include Earl Warren and William Brennan. ${ }^{47}$ Their tenure together on the Warren Court is often called the most consequential period in American judicial history since John Marshall shaped our public law from virtual nothingness. ${ }^{48}$ Looking at the

THE MAN AND THE JUdGE (1994)) (describing “creativity" and "the contribution that the decisions make to the development of legal rules and principles" as his preferred criteria for judicial greatness).

43 Fountaine, supra note 34, at 156-59.

44 See, e.g., Frederick Schauer, The Heroes of the First Amendment, 101 Mich. L. REV. 2118 (2003); see also Albert P. Blaustein and Roy M. Mersky, Rating Supreme Court Justices, 58 A.B.A. J. 1183, 1183 (1972) ("[T]he Court attains most of its glamour in dealing with the Bill of Rights.").

45 Paul Finkelman, Civil Rights in Historical Context: In Defense of Brown, 118 Harv. L. REv. 973 (2005) ("Most Americans at the time, and many scholars today, believe that the Lochner-era Justices were indeed villains because they seemed to favor big business at the expense of 'the people' and the working class. ... In the area of race relations and other forms of social prejudice, even more than in the Court's economic jurisprudence, Justices had the opportunity to act as heroes or villains. They have had the chance to support equality and fairness or to support prejudice and discrimination."). See Wendel, supra note 38, at 2 ("These 'orienting stories' reveal the characteristics of the lawyer that we all ought to admire; the lawyer is shown to be the friend of the outcast, the rock of stability, or the conscience of the community.").

46 See Christine Alice Corcos, "Who ya gonna c(s)ite?" Ghostbusters and the Environmental Regulation Debate, 13 J. LAND USE \& ENVTL. L. 231, 271 n.180 (1997); Kahn, supra note 8, at 106-07 ("Early Fiss did just that in order to free the judicial landscape for the moral heroes of the bench. The ambition was to free the judges - and those who would judge them - from the false promises of craft; to see clearly the possibilities for justice that fell within the parameters of judicial action; and to urge all of us to take up these judges as our modern heroes. . . The heroic judge will now save us from the moral failings of the bureaucratic state. Again, to do so he must first escape from a false notion of craft.").

47 See Ross, supra note 7, at 406 ("The Pederson-Provizer list of the top ten justices reads like an honor role of liberal heroes," including Warren and Brennan.). One could argue that Justice Hugo Black belongs on this pedestal as well.

48 Schwartz, Superstars, supra note 4, at 136 ("In terms of creative impact on the law, the Warren tenure can be compared only with that of Marshall himself."). Interestingly, although commentators from the past century have argued that Marshall was great for molding the Constitution, I agree with Professor Christopher Wolfe that "his greatness lies not in shaping an ambiguous document but in reading a great document faithfully. Marshall's greatness lay in effecting not his own will but the will of the law: the Constitution." Christopher WOLfe, The Rise of MODERN Judicial REview 41 (Rowman \& Littlefield 1986). In this magisterial volume, Wolfe traces the evolution of judicial review through American history. He demonstrates that in early American history, judges were expected to utilize judicial review in very rare instances of clear conflict between a law and the constitutional text. Judge Robert H. Bork has written that Wolfe's book is one of the five most important books ever written about 
"hero" rhetoric associated with each of these two justices, it becomes apparent that both display the characteristics outlined above.

Chief Justice Earl Warren, the former California governor who sat on the Court from 1953 to 1969 , is often described as heroic. ${ }^{49} \mathrm{He}$ is even compared to the man widely acknowledged as the greatest justice in American history, John Marshall. "The period when Earl Warren sat in the Supreme Court's central chair turned out to be, in Friendly's phrase, 'the most innovative and explosive era in American constitutional law' since the days of Marshall. . . . [H] is skill as a statesman enabled him to lead in the greatest judicial transformation of the law since the days of Marshall." most among the cases of that era is the unanimous decision in Brown v. Board of Education, ${ }^{52}$ for which Warren is listed alongside Lincoln and Robert H. Jackson as "lawyer-statesmen" by Yale Law Dean Anthony Kronman. ${ }^{53}$ Upon taking his place as the first incumbent in the Earl Warren Professorship at California Western School of Law, Michal R. Belknap said that Warren "looked like a larger-than-life heroic figure. . . . A generation of lawyers came out of law school wanting to follow in the footsteps of the Warren Court: to litigate the next big case that would establish the next important right for the less fortunate." more of the intellectual heavy lifting, it will always remain Warren's name that is borne by these decisions: "[e]ntire branches of the law really begin with rulings of Warren's Court." ${ }^{, 5}$ The rhetoric surrounding Warren's heroic status, then, is tied into the historic and transformative work of his court, and the sympathetic nature of those who benefited from these decisions.

Though Chief Justice Warren was the titular head of the Warren Court, Justice William Brennan is acknowledged as its primary architect. A symposium assembled by the Harvard Civil Rights-Civil Liberties Law Review in honor of Justice Brennan was entitled "Remembering a Constitutional

the Constitution, alongside Justice Story's COMMENTARIES and THE Federalist PAPERS. Robert H. Bork, We the People: Top Books on the Constitution, WAll StreEt J., Jan. 14, 2006, available at http://www.opinionjournal.com/weekend/fivebest/?id=110007813.

49 See, e.g., Paul Finkelman, Civil Rights in Historical Context: In Defense of Brown, 118 HARV. L. REV. 973, 995 (2005).

50 Akhil Reed Amar, Hugo Black and the Hall of Fame, 53 AlA. L. REV. 1221, 1221 (2002)

(asking "Who was the greater Chief Justice, John Marshall or Earl Warren?”).

51 Schwartz, Judicial Ten, supra note 4, at 434, 438.

52347 U.S. 483 (1954).

53 Anthony T. Kronman, The Lost LaWyer 3 (Belknap Press 1993).

54 Michal R. Belknap, Earl Warren Professorship Acceptance Speech, in 39 CAL. W. INT'L L.J. 366, 366-68 (2009).

55 Id. at 368 . 
Hero." ${ }^{56}$ Morton Horowitz of Harvard Law School inducted him into the "select pantheon of the greatest Supreme Court justices," alongside only Marshall, Holmes, and Brandeis. ${ }^{57}$ Kim Eisler concluded, " $[\mathrm{M}]$ ore than any other justice in United States history Brennan would change the way Americans live." 58 How did Brennan achieve such a status? Again, the rhetoric of heroism follows the activist mode. Well known opinion journalist Mickey Kaus, for instance, said that the press "tends to lionize judges (William Brennan, for example) who see their role as striking dramatic blows for social justice." ${ }^{59}$ Often he did this from the bench - Professor Bernard Schwartz titled an article on Brennan "A Lawgiver in Action." In the case of Brennan, he also struck such blows through his work launching the "new federalism revolution" for individual rights in the state courts. ${ }^{61}$ These activities all showed "his willingness to adapt [law] to meet the demands of [justice], ${ }^{, 62}$ or at least, his vision of justice. Professor Roy Schotland of Georgetown University Law Center listed among his strengths "his vision for our nation" and "his vision for his own role." ${ }^{63}$ How interesting to think of a judge possessing his own "vision for our nation," and to know that he has a "vision for his own role" that involves implementing that "vision for our nation." Professor Schotland concludes, "[t]he man is immortal.",64

How does a justice achieve immortality? Apparently it is only through aggressive, expansive (some may say activist) judging that a justice may become a hero. By wielding great power to implement a prophetic vision for the country and by shaping a future of individual liberty and rights that is especially solicitous of the poor and downtrodden, a heroic judge may transform the law and secure his legacy for history. This is how Warren and Brennan operated, and the hero-designators of the legal academy praise them for it.

\footnotetext{
56 E. Joshua Rosenkranz et al., Remembering a Constitutional Hero, 43 N.Y.L. SCH. L. REV. 13, 13 (1999).

57 Morton Horowitz, Remembering a Constitutional Hero, 43 N.Y.L. SCH. L. REV. 13, 18 (1999).

58 Kim I. Eisler, A Justice for All: William J. Brennan, JR., And the Decisions that TRANSFORMED AMERICA 13 (Simon \& Schuster 1993).

59 Mickey Kaus, Working Man, 30 LoY. L.A. L. REV. 963, 964 (1997).

60 Bernard Schwartz, Justice Brennan and the Brandenburg Decision - A Lawgiver in Action, 79 JUDICATURE 24 (1995). Elsewhere, Schwartz reports that the British newsmagazine The Economist headlined its story on Justice Brennan's retirement "A Lawgiver Goes." Schwartz, Superstars, supra note 4 , at 143 .

61 See Daniel O’Hern, Remembering a Constitutional Hero, 43 N.Y.L. SCH. L. REV. 13, 22 (1999).

62 Kevin O'D. Driscoll, The Origins of a Judicial Icon: Justice Brennan's Warren Court Years, 54 STAN. L. REV. 1005, 1034 (2002).

63 Roy Schotland, Remembering a Constitutional Hero, 43 N.Y.L. SCH. L. REV. 13, 23 (1999).

64 Id. at 27.
} 


\section{THE HEROISM OF ORIGINALISM}

In this next section, I will show that the activist model is not the only way to connect justices with a heroic tradition. ${ }^{65}$ Rather, judges who take an originalist approach to judging - one that emphasizes appropriate deference to the rule of law as the rule of law-makers - can aptly be considered the legal version of the humble hero. The humble hero is a much rarer breed than the active hero, harder to find in history, literature, and the judiciary. ${ }^{66}$ The classic, and classical, humble hero is the Roman statesman Cincinnatus. In the year 458 B.C., when a tribe from the northern region of Italy threatened the Roman Republic, the Senate turned to a patrician and former consul, Lucius Quinctius Cincinnatus. ${ }^{67}$ The Senate voted to invest him with the emergency powers of the dictator - a single ruler with absolute power throughout the Republic for a term of six months. ${ }^{68}$ The historian Livy reports that the Senatorial delegation found him working his fields behind a plow; before hearing their request, he called to his wife in their cottage to bring his toga so he could treat the matter with proper decorum. $^{69}$ He accepted, went to Rome, gathered the army, led the legions in a tough battle against the Aequians, and vanquished them. ${ }^{70}$ Sixteen days after taking office as dictator, he disbanded his troops and returned to his three acres. ${ }^{71}$ He thus became the historic standard for the humble hero, who took up power to save the nation, and gave it up just as soon as the job was done, evincing an "utter lack of political ambition.,"72

The general who was savior of our own nation, George Washington, is often described as the "American Cincinnatus" - Professor John M. Kang explains why:

We remember Washington as the 'perfect Cincinnatus, the Roman patriot who returned to his farm after his victories in war.' He devoted himself to his country, and, even though he could have exploited his

65 Indeed, some suggest that judges and scholars should be very careful when considering expansion of the hero label for the activist model outside of the historically unique Brown context. Patrick E. Higginbotham, Conceptual Rigor: A Cabin for the Rhetoric of Heroism, 59 TEX. L. REV. 1329 (1981).

66 See J. Malcolm Moore, Carl Vinson: Public Servant, Humble Hero, 33 MerCer L. ReV. 1, 1 (1981) ("Heroes are in short supply. Heroes filled with humility are so rare that their very existence is cause for celebration.").

67 William R. Nifong, Promises Past: Marcus Atilius Regulus and the Dialogue of Natural Law, 49 DuKE L.J. 1077, 1096 (2000).

68 Id.

69 See Cincinnatus, http://people.westminstercollege.edu/faculty/mmarkowski/H112/Cincinnatus .htm (last visited Dec. 1, 2009) (excerpting an English translation from book 3.26 of Livy’s history).

70 Nifong, supra note 67, at 1098.

71 Id.

72 Id. 
fame to obtain more political power, he resigned as commander-inchief of the colonial Army. By doing so, he offered for view a modesty that was virtually unimaginable, even for a gentleman. . . . Whereas the king had brutishly usurped power, Washington declined it in a gesture that is a monument to civility's gentle self-effacement. And whereas Paine's king arrogantly placed himself outside the rule of law, Washington's resignation represented a civility in which he preferred to don the egalitarian dignity of his fellow citizens than to bask in the privileged honor of the few. Evoking the older meaning of civility as citizenship, Washington bypassed a potential opportunity for emperorship to become a regular citizen. ${ }^{73}$

Both Washington and Cincinnatus were triumphant generals who could have chosen to seize power in the state after their victories. Both resisted this temptation, willingly laid down their powers, and instead returned to tending their farms.

If Washington and Cincinnatus embody the humble hero in history, then Frodo Baggins provides the best example from literature. ${ }^{74}$ Frodo, a hobbit of the Shire, is the central character in J.R.R. Tolkein's beloved tale The Lord of the Rings. ${ }^{75}$ In the first book of the trilogy, Middle-Earth is threatened by a resurgent evil force, Sauron. The only way to destroy Sauron is to destroy the object he seeks, a magical ring that gives its user great power. $^{76}$ But the ring can only be destroyed by throwing it into the fires of Mount Doom, the volcano where it was forged, in the heart of Sauron's

73 John M. Kang, Manliness and the Constitution, 32 Harv. J.L. \& PuB. POL'y 261, 310-11 (2009) (internal citations omitted).

74 I am not the first to compare the temptations of judicial power to those of the One Ring in The Lord of the Rings. Senator Orrin Hatch said on the floor of the Senate in 2006:

The temptation and danger of judges making law reminds me of a scene in The Fellowship of the Ring, the first installment of the Lord of the Rings trilogy. Gandalf the wizard has discovered that Bilbo's ring is indeed the One Ring of power and Frodo insists that he take it. Gandalf wisely says: "Understand Frodo, I would use this ring from the desire to do good. But through me, it would wield a power too great and terrible to imagine." In that same spirit, Justice Scalia declines the power to make law.

109 Cong. ReC. S10122 (daily ed. Sept. 20, 2006) (statement of Sen. Hatch). See Thomas L. Jipping, Which is to be Master?: The People, Judges, and the Constitution's Meaning, 2 LiBerTy U. L. REV. 419, 441 (2008) (Mr. Jipping served as counsel for Senator Hatch).

75 See Stefan Lovgren, The Lord of the Rings Honors Humble Heroism, Historian Says, NAT'L GEOGRAPHIC NEWS, Dec. 5, 2003, http://news.nationalgeographic.com/news/2003/12/1205_031205_lor doftherings.html. The three core volumes of the trilogy are THE FELLOWSHIP OF THE RING (1954), THE Two TOWERS (1954), and THE RETURN OF THE KING (1955).

76 See Gina Dalfonzo, Humble Heroism: Frodo Baggins as Christian Hero in The Lord of the Rings, In PURSUIT OF TRUTH: A J. OF Christian SCHOlarShIP, http://www.cslewis.org/journal/?p=16 ("The Ring is a constant temptation to power, playing on the desire for greatness of those who carry it."). 
fortress. A fellowship, composed of members of the various races of Middle-Earth, humans, dwarfs, hobbits, and elves, is commissioned to escort the ring-bearer safely to this dangerous destination.

Throughout the trilogy, various good characters contemplate carrying the ring: Gandalf, the wizard; Elrond, leader of an elven clan; Boromir, son of the steward of Gondor; and Galadriel, an elven queen. All see the ring's potential to do good, ${ }^{77}$ but also the terrible danger that they will fail to do only good. For instance, Frodo's companion Sam urges Galadriel to take the ring, saying, "[y]ou'd put things to rights. . . . You'd make some folk pay for their dirty work." She replies, "I would. . . . That is how it would begin. But it would not stop with that, alas." carrying the ring falls to Frodo, the unlikeliest member on a team that includes a prince, a future king, and a wizard, but the only one up to the task.

Frodo "accepted it with humility, resolved to renounce it," then set out "toward the destruction of the very artifact of power. ... [a] Quest . . . based on the recognition of corruptibility and the renunciation of (unbridled) power." 79 Throughout the books, Frodo "must fight constantly the temptation to claim it for his own and gain its power for himself." ${ }^{80}$ Frodo's final success in his endeavor indicates that Lord Acton's time honored observation, "power tends to corrupt and absolute power corrupts absolutely," is not true in every instance. ${ }^{81}$ Though not without difficulty, and moments of severe trepidation and major decision, Frodo's achievement shows that a firm will and a stout heart can resist succumbing to the temptations of raw power when motivated by nobler goals and higher ends.

Which judicial ideology best resembles the humble heroism of Frodo? Humble judicial heroism begins by recognizing the great power invested in judges, and a resolution like Frodo's to renounce the use of the power for

77 Gandalf, for instance, states: "[T] he way of the Ring to my heart is by pity, pity for weakness and the desire of strength to do good." J.R.R. TOLKIEN, THE FELLOWSHIP OF THE RING 88 (Ballantine Books ed. 1954). Elrond states:

If any of the Wise should with this Ring overthrow the Lord of Mordor, using his own arts, he would then set himself on Sauron's throne, and yet another Dark Lord would appear. And that is another reason why the Ring should be destroyed: as long as it is in the world it will be a danger even to the Wise. For nothing is evil in the beginning. Even Sauron was not so. I fear to take the Ring to hide it. I will not take the Ring to wield it.

Id. at 321 .

78 Id. at 432

79 Rico M. Abrahamson, Stages of Imagination: Exploring the Theme and Vision in J.R.R. Tolkien's Middle Earth, http://valarguild.org/varda/Tolkien/encyc/papers/dreamlord/stages/ humble_hero.htm (last visited Mar. 19, 2010).

80 Dalfonzo, supra note 76.

81 Though it still is in most! 
personal priorities. ${ }^{82}$ Second, the humble hero undertakes his office as a service to others, to his nation as a servant of the rule of law.

Professor Brett Scharffs of Brigham Young University School of Law has written, "A humble judge will have a better understanding than a prideful judge of his own role within the legal system, and will have an attitude, not of subservience, but of respect for the sources of authority that constrain and guide his behavior." " In a word, then, the judicial "humble hero" is an originalist. An originalist judge seeks to apply the law as it was passed by the ratifying authority, without any reference to his own personal beliefs. ${ }^{84}$ Professor Larry Lessig explains how humility and originalism connect by analogizing statutory interpretation to language translation:

Humility means this: to avoid translations that the translator believes make the text a better text; to choose instead translations that will carry over a text's flaws as well as its virtues. This counsel to humility is offered as a virtue in the translator's practice. . . On this view of the translator's task, fidelity requires a certain restraint - the restraint to minimize the voice of the translator in the text being translated. This is the integrity of the linguistic translator - an integrity that guides and constrains the translator in the practice of translation. Both dimensions of this integrity - setting the end of the translation, and practicing humility within that end - link the practice of the linguistic translator with the practice of the judge. For the judge as well must select the kind of fidelity that her reading will preserve, and she must pursue that fidelity constrained by an analogous form of humility. ${ }^{85}$

A judge who follows Professor Lessig's method, in other words, an originalist, understands his role in our constitutional system of government. ${ }^{86}$ He possesses the modesty to know that his role is important but not powerful, at least, when rightly exercised - obviously a Supreme Court justice who chooses to impose his own version of what is just and good has great power to do so.

82 See Brett Scharffs, The Role of Humility in Exercising Practical Wisdom, 32 U.C. DAVIS L. REV. 127, 189-93 (1998).

83 Id. at 186.

84 See Jamal Greene, On the Origins of Originalism, 88 TEX. L. REV. (forthcoming 2010) (manuscript at 1), available at http://ssrn.com/abstract=1357541.

85 Lawrence Lessig, Fidelity and Constraint, 65 FordHAM L. REV. 1365, 1372 (1997).

86 See John G. Roberts, Opening Statement to the Senate Judiciary Committee (Sept. 12, 2005), available at http://www.americanrhetoric.com/speeches/johnrobertsenatejudiciaryaddress.htm. 
This said, using originalist methods of interpretation in any individual case does not make a justice a "humble hero." ${ }^{, 87}$ Over the course of a judicial career, the touchstones of a true originalist are consistency and authenticity. Justices should always approach cases from an originalist perspective - there is no noble motive when a justice follows an originalist method to arrive at some decisions, then follows his personal values in other decisions. If one is convinced that originalism is the right method for constitutional interpretation - that it appropriately reflects the limited, servant role of judges in our republic - then one ought to use it consistently. Of course, no justice is perfect, and some will question whether particular decisions are truly originalist. ${ }^{88}$ Still, clearly some judges are committed to using originalism when they decide cases and are not afraid to say so. ${ }^{89}$

Consistency must be matched with authenticity. Originalism should not be a cover for the implementation of a judge's personal agenda when that agenda is advanced by wrapping it in originalist rhetoric. Instead, a justice should authentically apply an originalist methodology to all cases before him. In short, an originalist judge will from time to time rule against what one would expect to be his personal policy preference in a given case.

Justice Scalia provides an excellent example of an judge who follows an originalist methodology, even when it conflicts with his expected policy preferences. $^{90}$ Two areas of Justice Scalia's jurisprudence illustrate this well. First are his decisions in the Sixth Amendment context. Observers expect Justice Scalia to act as a law-and-order Reagan appointee, ${ }^{91}$ and his track record on the Court has made him "the darling of tough-on-crime conservatives." ${ }^{.92}$ Yet in cases decided under the Amendment's Confrontation

87 Some argue that both the majority and the main dissent in D.C. v. Heller, $128 \mathrm{~S}$. Ct. 2783 (2008), for instance, followed an originalist inquiry. See, e.g., Greene, supra note 84, at 1 (commenting on how "interesting" it was that "Justice Steven's lengthy dissent spent so much time parsing the views of eighteenth-century Americans on the meaning of the Second Amendment's text.").

88 See, e.g., J. Harvie Wilkinson, Of Guns, Abortions, and the Unraveling Rule of Law, 95 VA. L. REV. 253, 256 (2009) (questioning Justice Scalia's commitment to originalism in Heller); Richard A. Posner, "In Defense of Looseness: The Supreme Court and Gun Control," NEW REPUBLIC, Aug. 27, 2008 , at 32 .

89 See, e.g., William H. Rehnquist, The Notion of a Living Constitution, 54 TEX. L. REV. 693 (1976); Antonin Scalia, Originalism: The Lesser Evil, 57 U. CIN. L. REV. 849 (1989); RoBerT H. Bork, The Tempting of America; The Political Seduction of the LaW (Touchstone Books 1990).

$90 \mathrm{He}$ is hardly the only example. For a recent example of another such case, see City of Milwaukee Post No. 2874, Veterans of Foreign Wars v. Redevelopment Auth. of the City of Milwaukee, 2009 WI 84, ๆ 83-87 (Ziegler, J., concurring) (stating that sympathy for a particular litigant should not alter the result when the litigant should lose under the established law).

91 See James Vicini, Justice Scalia Defends Bush v. Gore Ruling, REUTERs, Apr. 24, 2008, http://www.reuters.com/article/idUSN2429912220080424 ("I am a law-and-order guy. I mean, I confess to being a social conservative, but it does not affect my views on cases.").

92 Stephanos Bibas, Originalism and Formalism in Criminal Procedure: The Triumph of Justice Scalia, the Unlikely Friend of Criminal Defendants?, 94 GEO. L.J. 183, 184 (2005). 
Clause, Justice Scalia has been on a two-decade long march to transform the Court's precedent to better reflect the text of the clause, which has led to several significant decisions favoring the defendant. ${ }^{93}$ Similarly, under the Amendment's jury clause, Justice Scalia has consistently held that the original meaning of the text requires certain rights for criminal defendants. ${ }^{94}$ These decisions have led Professor Stephanos Bibas of Penn Law to label him "the unlikely friend of criminal defendants."

A second line of cases which illustrate Justice Scalia's restraint are the First Amendment's flag-burning cases. ${ }^{96}$ A report on a speech by Justice Scalia to the College of William \& Mary presents the matter well:

As a staunch conservative, U.S. Supreme Court Justice Antonin Scalia says he doesn't carry any deep affection for 'bearded, sandal-wearing weirdos' who choose to express their First Amendment rights by burning the American flag. However, as an originalist - one who interprets the U.S. Constitution based on the meaning it held when it was originally adopted more than 200 years ago - burning the American flag is a protected right . . . . 'It's protected by the First Amendment,' said Scalia .. . 'If you play the old way, you often have to reach decisions you don't enjoy."

These cases provide a few examples of areas of the law where Justice Scalia places an originalist interpretive philosophy ahead of his personal ideo-

93 See, e.g., Melendez-Diaz v. Massachusetts, 129 S. Ct. 2527 (2009); Giles v. California, 128 S Ct. 2678 (2008); Crawford v. Washington, 541 U.S. 36 (2004); Maryland v. Craig, 497 U.S. 836, 862-70 (1990) (Scalia, J., dissenting); Coy v. Iowa, 487 U.S. 1012 (1988).

94 See Oregon v. Ice, 129 S. Ct. 711, 720 (2009) (Scalia, J., dissenting); Blakely v. Washington, 542 U.S. 296 (2004); Apprendi v. New Jersey, 530 U.S. 466 (2000). Interestingly, the direction of both of these Sixth Amendment clauses may change with the replacement of Justice Souter by Justice Sotomayor. Justice Souter typically joined Justices Scalia, Thomas, Stevens, and Ginsburg to make a five vote majority in these cases. Justices Breyer has generally been in dissent. It is unclear whether Justice Sotomayor will follow the Stevens-Ginsburg thought of the Court's liberals or Justice Breyer's. See Michael O'Hear, "Are the Court's Unexpected Sixth Amendment Revolutions Coming to an End?", Marquette University Law School Faculty Blog, http://aw.marquette.edu/facultyblog/2009/12/03/arethe-courts-unexpected-sixth-amendment-revolutions-coming-to-an-end/ (Dec. 3, 2009).

95 Bibas, supra note 92, at 183. Were he to broaden his article beyond criminal procedure, Professor Bibas could also have added Smith v. United States, 508 U.S. 223, 246-47 (1993) (Scalia, J., dissenting) (arguing that a textualist interpretation of "use" a gun does not normally extend to uses other than as a weapon) and Kyllo v. United States, 533 U.S. 27 (2001) (holding that the use of thermal imaging equipment constitutes a search which requires a warrant under the Fourth Amendment).

96 See United States v. Eichman, 496 U.S. 310 (1990); Texas v. Johnson, 491 U.S. 397 (1989).

97 Bryan Whitson, Justice Antonin Scalia: The Case for a 'Dead Constitution,' W\&M NEws, Mar. 21, 2004, available at http://web.wm.edu/news/archive/index.php?id=3486. As a high school student, the author had the opportunity to hear Justice Scalia make the same point about Texas v. Johnson in person during a speech by the Justice at Marquette University. See Tom Kertscher, Scalia Slams 'Living' Document Philosophy, Milwaukee J. Sentinel, Mar. 13, 2001, available at http://www.encyclopedia.com/doc/1G1-121188953.html. 
logical preferences. In other words, they show that he exercises the heroic self-restraint which I have discussed earlier in this section.

In sum, then, an originalist justice like Justice Scalia appreciates the limited role given him by the Constitution. He acknowledges that his job is to serve the law by implementing the laws passed by the political branches. It is the political branches, as the elected representatives of the people, who should possess "a vision for the nation" that they enact into particular statutes. It is the judicial branch that is charged with applying the particulars of these laws to facts before them, not to implement the justices' own "vision for the nation." A humble hero on the bench knows this about his role, and seeks to serve the country by enforcing the rule of law.

Having identified judicial humble heroism with originalism, one might object that I have given no consideration to three other attributes of judicial decision-making that might fit the bill I have set: strict adherence to precedent, narrow resolution of cases, and deference to the constitutionality of congressional enactments. ${ }^{98}$ I take each in turn.

Judicial humble heroism, as I have defined it, first requires a justice to recognize the great power that has been given to him, and to refuse the temptation to use that power to implement his own vision of the good and just society. Yet he still must resolve cases before him. To do so, he must go outside himself, outside his own vision for what is good and just, and instead place his office at the service of another's vision. The natural next question, then, is whose vision the justice ought to implement if not his own. I have already answered that the justice should follow an originalist approach that is faithful to the vision of the democratic authorities (as made law through the ratification of the Constitution, the enactment of legislation, or the issuance of regulations).

But, one might object, precedent can serve the same function: it is a source of law outside the justice himself that he may turn to and use to implement another's vision for society. While this is true, I have already established that it is not the role of the judge to implement his own vision for society. Decisions where one judge has done so are a violation of his oath, and humble heroes who follow should not simply ratify and obey the un-

98 In the view of Justice John Paul Stevens, a Ford appointee who recently announced his retirement from the Court, the first two attributes define a "judicial conservative." Stevens told a reporter in late 2006, "I can see myself as a conservative, to tell you the truth, a judicial conservative." Jan Crawford Greenburg, Supreme Court Justice Stevens Remembers President Ford, ABC News, Jan. 2, 2007, available at http://abcnews.go.com/Politics/story?id=2765753\&page=1. In an interview with another reporter several years later, Stevens said that a judge can be "conservative by deciding cases narrowly and paying attention to (precedent)." Joan Biskupic, Supreme Court's Stevens keeps cards close to robe, USA TODAY, Oct. 19, 2009, available at http://www.usatoday.com/printedition/news/20091019/1asteve ns19_cv.art.htm. 
humble actions of their predecessors. Judges are servants of the law, not of those who decided previous cases.

One might also object that a judicial humble hero must be an "incrementalist" who strives for a narrow resolution of the cases before him. In fact, however, this is an activist approach that would result in the imposition of the judge's own vision on the law. Analogy can be made here to statutory and constitutional construction. Beginning with President Nixon, Republican presidents have promised to appoint "strict constructionist" justices to the bench. ${ }^{99}$ Yet Justice Scalia has accurately critiqued the phrase in his book, A Matter of Interpretation: "I am not a strict constructionist, and no one ought to be. . . . A text should not be construed strictly, and it should not be construed leniently; it should be construed reasonably, to contain all that it fairly means." 100 Although Republican politicians continue to use the phrase "strict constructionist judges," 101 Scalia's "reasonable" construction is much more widely accepted in the academy and on the bench. ${ }^{102}$ Just as it is "activist" to intentionally construe a text more broadly than it bears, it is also "activist" to interpret a text more narrowly than the text justifies. $^{103}$ To do so is to impose the judge's personal proclivities on the case $^{104}$ - to act as an activist hero, not a humble hero.

99 Jeffrey Rosen, Can Bush Deliver a Conservative Court?, N.Y. TIMES, Nov. 14, 2004, available at http://www.nytimes.com/2004/11/14/weekinreview/14jeff.html ("By promising to appoint strict constructionists, Mr. Bush has embraced the mantra of every Republican president since Richard Nixon, who first made that promise in his 1968 campaign."); see Elliot E. Slotnick, Appellate Judicial Selection During the Bush Administration: Business as Usual or a Nuclear Winter?, 48 ARIZ. L. REV. 225, 228 (2006) (quoting from a memorandum by a Nixon White House aide: "Perhaps the least considered aspect of Presidential power is the authority to make appointments to the federal bench - not merely to the Supreme Court, but to the Circuit and District benches as well. Through his judicial appointments, a President has the opportunity to influence the course of national affairs for a quarter of a century after he leaves office.").

100 Antonin Scalia, A Matter of Interpretation 23 (Amy Guttman ed., 1997); see John J. Miller, Between the Covers: Robert H. Bork on a Time to Speak, NAT'L REV. OnLINE, Jan. 16, 2009, http://radio.nationalreview.com/betweenthecovers/post/?q=MjllMDc0MjJiMjM3YzgzYjhmMWI4YzJk NTM0M2UzMDU = ("I don't know what strict constructionism is. . . . I want reasonable construction, which means a reasonable interpretation of the words and the history of the Constitution."). Rather than saying "reasonably," I wish Justice Scalia and Judge Bork had said "normally." There may be several "reasonable" readings of a term, and one can argue whether something is "reasonable" or which of the "reasonable" options is the "right" reading. But to give a term its "normal" meaning would, I think, be a more accurate description of the type of construction Justice Scalia or Judge Bork gives to a term.

101 See, e.g., Ray Rivera, Giuliani Shifts Abortion Speech Gently to Right, N.Y. TIMES, Feb. 10, 2007, available at $\mathrm{http}: / / w w w . n y t i m e s . c o m / 2007 / 02 / 10 /$ us/politics/10rudy.html.

102 See John Hart Ely, Democracy and Distrust 1 (Harvard Univ. Press 1980) (contrasting "strict constructionism" with originalism/interpretivism).

103 See Citizens United v. FEC, 130 S. Ct. 876, 892 (2010) ("It is not judicial restraint to accept an unsound, narrow argument just so the Court can avoid another argument with broader implications. Indeed, a court would be remiss in performing its duties were it to accept an unsound principle merely to avoid the necessity of making a broader ruling. "); id. at 4 (Roberts, C.J., concurring) (“[W]e cannot 
In the same way, a justice should not seek to artificially narrow or broaden the resolution of a case. A judge is not an itinerant knight roaming abroad seeking unconstitutional statutes to slay, ${ }^{105}$ and judges should not use cases as opportunities to pronounce sweeping rules unnecessary for the resolution of the case before them. At the same time, a justice of the Supreme Court sits on the highest court in the land, and is not in the business of error correction. A ruling that is forcibly narrowed provides insufficient guidance for lower courts to resolve future cases. Thus, just as in construction, a justice should offer a reasonable resolution of the case. To do otherwise is to replace the rule of law with the judge's personal preferences, regardless of whether that preference is for broad or narrow rulings. Incrementalism may have its virtues, but it is a false modesty when it artificially forces a narrower resolution than the law reasonably calls for. A humble judge resolves cases as the law dictates, without forcing on them his personal desire for a broad or narrow resolution.

Moreover, judicial humble heroism is not to simply do the opposite of liberal activist heroism. Just because liberal heroes are especially sympathetic to the poor and oppressed does not mean that a humble hero ought to be inclined to favor the rich and powerful. Similarly, just because liberal heroes decide cases with broad, sweeping decisions, ${ }^{106}$ that does not mean a humble hero must insist on narrow resolution of cases. Rather, as previously explained, the humble hero gives reasonable application to the democratically-enacted law.

Additionally, judicial minimalism or incrementalism in no way guarantees that its practitioners are practicing humble heroism as I have defined it. A justice could vote for a narrow decision in a case, but that decision could still reflect his personal sense of what is "just" and "good" policy in that narrow area, or even in only that particular case. In fact, the individual resolution of cases would empower a judge to dispense particular justice as he sees it in each instance. ${ }^{107}$

embrace a narrow ground of decision simply because it is narrow; it must also be right. . . There is a difference between judicial restraint and judicial abdication.").

104 See Edward M. Whelan, III, Introducing 'This Week in Liberal Judicial Activism, ' NAT'L REV. Jan.

19, 2007, available

http://bench.nationalreview.com/post/?q=NWMyNzlmOGZhOWQ5YjY0YjNmYmI5MGM5Y2MxMz $\mathrm{M} 3 \mathrm{ZDU}=$ ("I intend to use the term 'judicial passivism' for judicial decisions that make the opposite error-that fail to enforce constitutional guarantees.").

105 Wolfe, supra note 48, at 103.

106 See also Michael B. Brennan, Are courts becoming too activist?, MiLwAUKEE J. SENTINEL, Oct. 1, 2005, available at http://www3.jsonline.com/story/index.aspx?id=359831.

107 See Antonin Scalia, The Rule of Law as a Law of Rules, 56 U. CHI. L. REV. 1175 (1989). 
Others, such as Justice Stephen Breyer, define judicial humility or modesty to require the Court to "consider the constitutionality of statutes with a certain modesty." 108 While the Court should always be respectful of the other branches, ultimately the separation of powers invests the judiciary with "the judicial power." "The Court remains duty-bound to analyze the Constitution, as a higher law than statutes, independent of the other branches, and to enforce its mandates even, perhaps especially, when they conflict with the desires of another branch: "In the final analysis, it is the judicial department that must decide questions of constitutional construction, irrespective of the practice of the other departments of government."110

Finally, it is important to say something about the nobility of judicial humility, as I have used the term. There are several other ways that the concept of "humility" is used in the legal literature in connection with the judicial office. One is to say that justices are "humble" when they achieve "an understanding of the range of the problems and of their own inadequacy in dealing with them." "Another strain associates judicial humility with, in Hand's phrase, "the spirit which is not too sure that it is right." "12 Yet another says that humility "enables lawyers to learn from their mistakes," and results in openness to new information and change. ${ }^{114}$

Though all these characterizations may draw on the concept of humility, none do so in the heroic sense in which I have used it. Judicial humble heroism stems from noble motives, from an appreciation for the proper role of the judge in our constitutional system of government. Although an acknowledgement of the judiciary's lack of information compared to the legislative branch may lead a judge to an originalist philosophy, it is not a noble motive. Recognition of this limitation may be humble in some sense, but it does not foreclose the possibility of a judge imposing his own sense of what is good policy if he did have what he considered sufficient information. Moreover, he does not need any outside information to determine his own sense of morality or justice. Similarly, though a judge may issue more

108 Stephen Breyer, Our Democratic Constitution, 77 N.Y.U. L. REv. 245, 250 (2002).

109 U.S. CONST. art. III, § 1, cl. 1.

110 John Sundquist, Construction of the Wisconsin Constitution-Recurrence to Fundamental Principles, 62 MARQ. L. REV. 531, 553 (1979).

111 Felix Frankfurter, Chief Justices I Have Known, 39 VA. L. REV. 883, 905 (1953); see also Felix Frankfurter, Mr. Justice Roberts, 104 U. PA. L. REV. 311, 312-13 (1955) (praising Justice Roberts for his "humility engendered by consciousness of limitations"); Scharffs, supra note 82, at $185 \mathrm{n} .148$ (recounting Justice Frankfurter's description of Justice Holmes' humility).

112 Learned Hand, The Spirit of Liberty, in THE SPIRIT OF LIBERTY: PAPERS AND ADDRESSES OF LEARNED HAND 189, 190 (Irving Dilliard ed., 3d ed. 1960).

113 Chenise S. Kanemoto, Bushido in the Courtroom: A Case for Virtue-Oriented Lawyering, 57 S.C. L. REV. 357, 374 (2005).

114 Scharffs, supra note 82, at 164. 
limited or restrained decisions because he feels uncertain about their accuracy, this is not a noble motive. And while it is good and worthy to be willing to learn from mistakes, this too fails to focus on the willful laying down of power in service to the republic.

The sacrifice of power in service to society is the theme shared by the stories of the Roman statesman Cincinnatus, the American statesman George Washington, and the literary hero Frodo Baggins. Each of them turned aside the prospect of personal power and instead exercised a form of heroic self-control that placed their fellow citizens first. In the same way, justices who consistently and authentically follow an originalist theory of interpretation practice this virtue of humble heroism. They refuse the temptation to impose their own vision and values on American society, and instead respect their limited role as servants of the laws enacted by the people through their elected representatives and delegated regulators.

\section{CONCLUSION}

Although celebrities may have generally replaced heroes in modern American culture, the legal community continues to lift up the best of its members as heroes. Those justices who achieve this distinction, as conferred by the opinion leaders in the academy and elsewhere, typically fit the usual pattern of heroes from culture at large: pioneers, reformers, wielders of power and welders of coalitions, champions of the poor and oppressed. Thus, Chief Justice Warren and Justice Brennan are considered as constitutional heroes by the legal community. Once ensconced on the legal Mount Olympus, they and other liberal heroes serve as role models for those who aspire to join their august company: current judges, lawyers, and law students. Moreover, the citizenry at large considers the designated legal heroes and the roles they played while on the Court when deciding what role they believe the Court as a whole ought to play in public life.

Yet there is another tradition of heroism - rarer but perhaps more noble. The Roman general Cincinnatus set the classical standard when he refused to overthrow the republic for a permanent dictatorship in the wake of his victory, returning instead to the simple labors of his farm. The American general George Washington chose the same path at the end of the Revolutionary War, choosing the fields of Mount Vernon rather than erecting a new monarchy with himself as its founding father. In a much more sustained effort, Frodo Baggins makes it across much of Middle-Earth with the constant companionship of the One Ring that would give him supreme power. But the humble hobbit of the Shire foreswore such power daily, maintaining his resolution to bear the ring but not to use it.

Judges too may tap into this tradition of humble heroism. Originalist judges understand and respect the necessary limits of their role. Rather 
than imposing their own versions of "justice" and "good," they follow the rule of law as the rule of democratically-elected legislators. Those justices who consistently and authentically follow an originalist methodology over the course of a judicial career rightly deserve the moniker "humble heroes."

In fact, they may be the only judges who deserve the label "hero." 115 Tolkien scholar Gina Dalfonzo may be right when she says that he teaches, "the greatest heroism is the victory over self for the sake of others - that, in fact, there can be no heroism where there is no possibility of succumbing to temptation." If so, liberal judicial heroism is the consistent indulgence of the temptation to power, and thus no heroism at all, simply activism.

115 Articles that were helpful but were not cited elsewhere in the paper are: Marie A. Failinger, Gentleman as Hero: Atticus Finch and the Lonely Path, 10 J.L. \& RELIGION 303 (1994); Charles Fairman et al., The Writing of Judicial Biography - A Symposium, 24 IND. L.J. 363 (1948); Michael W. McConnell, The Importance of Humility in Judicial Review: A Comment on Ronald Dworkin's 'Moral Reading' of the Constitution, 65 FordHAM L. REV. 1269 (1997); John T. Noonan, Jr., The Secular Search for the Sacred, 70 N.Y.U. L. REV. 642 (1995); David Ray Papke, Crusading Hero, Devoted Teacher, and Sympathetic Failure: The Self-Image of the Law Professor in Hollywood Cinema and in Real Life, Too, 28 VT. L. REV. 957 (2004); Margaret Raymond, Criminal Defense Heroes, 13 WiDENER L.J. 167 (2003); Suzanna Sherry, Judges of Character, 38 WAKE FoREST L. REV. 793 (2003).

116 Dalfonzo, supra note 76. 